An erratum slip has been inserted into the bound volumes which we can get hold of and the offending page will be reprinted in those still unbound. I would, however, be most grateful if you could give publicity to this most regrettable error and oversight in proof reading.- $\mathrm{I}$ am, etc.,

Edinburgh.

\section{DeRRICK DUNLOP.}

\section{Diet in Chronic Renal Failure}

SIR,-Dr. J. Ford and others (22 March, p. 735) appear surprised at the differences between their results and ours in the treatment of chronic renal failure by diet, and have consequently drawn the erroneous conclusion that a $70 \mathrm{~kg}$. man with renal failure should have $35 \mathrm{~g}$. of protein. Having treated 300 patients in advanced renal failure (glomerular filtration rate (G.F.R.) $5 \mathrm{ml}$. per minute) with our diet in the past five years, may we be permitted the following observations?

Our diet contains 18-21 g. of pratein based on high biological value whole egg and milk, and adequate calories. ${ }^{1}$ Its essential amino-acid content, together with $250 \mathrm{mg}$ oral methionine, is adequate for the minimal daily requirements. If less than the minimal requirements of any of the essential aminoacids are given, negative nitrogen balance will ensue. This is a basic fact of nutritional biochemistry, ${ }^{23}$ yet Dr. Ford and his colleagues in three of their patients did not give the minimal requirements of the essential amino-acids. When we were designing our modified Giovannetti diet we gave much thought to the problem of whether to use meat or eggs, but we chose whole egg because the essential amino-acid requirements can be met with less nitrogen by whole egg than by meat.

This is one of the essential differences between our diet and that of Dr. Ford and colleagues. The required essential amino-acid content found in one egg or $200 \mathrm{ml}$. of milk is found in $1 \frac{1}{2} \mathrm{oz}$. $(45 \mathrm{~g}$.) of meat or chicken. Unfortunately, $\mathrm{Dr}$. Ford and colleagues give dietary details of only Cases 8 and 16. Only the former is in the really low protein range; this patient ate meat and consumed $24 \mathrm{ml}$. of milk daily. If we correct our egg and milk 18-21 g. diet to a diet equivalent in essential amino-acid content containing $24 \mathrm{ml}$. of milk and meat it will requir $10.5 \mathrm{~g}$. of meat protein to replace one egg and $9 \cdot 2 \mathrm{~g}$. of meat protein to replace the 176 ml. of milk-that is, $19.7 \mathrm{~g}$. of meat proteininstead of $13.6 \mathrm{~g}$. of $\mathrm{egg}$ and milk protein. The total protein intake of this diet should be $24 \cdot 7$ to $27 \cdot 7 \mathrm{~g}$. per 10 stone $(70 \mathrm{~kg}$.) subjectthat is, 0.39 to $0.44 \mathrm{~g}$. of protein $/ \mathrm{kg}$. -in Dr. Ford and colleagues' safe range from the point of view of $\mathrm{N}$ balance. Their Case 8 had 0.48 g. of protein per kg., so that the principal difference between our diet and that of Dr. Ford and colleagues, in so far as one can derive it from their paper, is that we can supply the essential amino-acid requirements with less nitrogen-that is, in the form of whole egg, than they can using meat. The lower the protein conten the better, assuming that the diet is palatable and the required essential amino-acids and calories are present. Our diet fulfils thes criteria better than that of Dr. Ferd and his colleagues.

In outpatients, faecal collections and dietary aliquots cannot be readily measured. We measured urinary nitrogen excretion, a method sanctioned by Albanese and Orto."
We added a correction for faecal nitrogen and assessed nitrogen intake clinically and used a biochemical check, the serum urea/serum creatinine ratio, which falls te about half its predietary value on our diet. We used a microKjeldahl technique for measuring nitrogen. Precise nitrogen balances have been carried out on inpatients with advanced renal failure on our diet by Professor S. W. Stanbury (personal communication) in which nitrogen balance or positive balance was achieved in four patients studied for up to 80 days.

Our patients do not have kwashiorkor. They have normal serum albumin and serum transferrin levels.

Tables of methionine and cystine requirements in woman are readily available. ${ }^{23} \mathrm{Dr}$. Ford and his colleagues have misquoted Davidson and Passmore's Table 5, 6, which gives this requirement for women but not for men."

We do not give rigid protein restriction to patients with glomerular filtration rates above $5 \mathrm{ml}$. per minute, unlike the majority of the patients of Dr. Ford and others, who have creatinine clearance higher than $5 \mathrm{ml}$. per minute. Unless the patient experiences the relief of gastro-intestinal symptoms by taking the diet, he cannot be expected to adhere to the diet. If the G.F.R. is $3 \mathrm{ml}$. per minute or less then the $18-21 \mathrm{~g}$. diet is lifesaving and enables the patient to survive months or years (depending on the disease) at blood urea levels below $200 \mathrm{mg} . / 100 \mathrm{ml}$. when he may well have died on the $35-\mathrm{g}$. diet recommended by Dr. Ford and his colleagues. There will never be enough space for dialysis or transplantation of all patients with terminal renal disease. They can, however, have their lives prolonged and the quality of living improved by a diet such as ours.-We are, etc., \section{E. M. Booth. \\ Department of Medicine, iversity of Manchester, Royal Infirmary,}

G. M. BERLYNe

REFERENCES

Shaw, A. B., Bazzard, F. J., Booth, E. M., Niwarangkur, S., and Berlyne, G. M. Quarterly fournal of Medicine, $1965,34,237$. Biochemistry, edited by A. A. Albanese, 1965, Biochemistry, edited by A. A. Albanese, 1965, 2, pp. 127, 129. New York, Academic Press.
Hegsted, D. M., in Nutrition in Renal Disease,
edited by G. M. Berlyne, 1968., pp. 3, 11, 12. Edinburgh, Livingstone.

4 Albanese, A. A., and Orto, L. A., in Newer Methods of Nutritional Biochemistry, edited by
A. A. Albanese, 1963, 1, p. 3 . New York, Academic Press.

Berlyne, G. M., Mallick, N. P., and Gaan, D., in Fourth Symposium on Advanced Medicine, edited by O. M. Wrong, 1968, p. 103. London, Pitman Medical.

McFarlane, H., et al., Lancet, 1969, 1, 392. Nutrition and Dietetics, 3 rd ed, 1966 , Human burgh, Livingstone.

\section{Nephrotic Syndrome with Heart Disease}

SIR,-Recently (7 September, p. 584) we suggested that the evidence for the common belief that heart failure alone may cause a nephrotic syndrome was inadequate. Mercurial diuretics have been given to 23 of the 24 well-substantiated cases of nephrotic syndrome associated with heart disease, and these compounds cannot be exonerated from nephrotoxicity in such patients. In our report we described two patients with neph- rotic syndrome and heart disease. This letter concerns the subsequent history of Case 1 in that report.

When first admitted to hospital this woman had developed a nephrotic syndrome after nine months' therapy with mersalyl for heart failure due to mitral valvular disease. During this first admission the jugular venous pressure was not elevated and there was no pulmonary oedema. We pointed to the difficulty of assessing cardiac function by the venous pressure in the presence of the hypovolaemia which may complicate the nephrotic syndrome. Renal biopsy showed minimal glomerular changes only and a complete remission occurred in response to prednisone.

For 14 months the patient was well and free from both oedema and proteinuria. Then she became dyspnoeic and oedema returned. On readmission to hospital she presented the classical picture of congestive cardiac failure, with elevation of the jugular venous pressure to $4 \mathrm{~cm}$. above the sternal angle. There was considerable pulmonary and generalized oedema. Proteinuria had returned, but only to the extent of $1 \mathrm{~g} . / 24$ hours; the plasma albumin level remained normal at $4.7 \mathrm{~g} .1100 \mathrm{ml}$. The cardiac failure responded to standard therapy (without mercurials) and the proteinuria disappeared within seven days.

Thus when the patient developed the nephrotic syndrome she was receiving mersalyl, but lacked the classical features of cardiac failure. Eighteen months after stopping mersalyl undoubted cardiac failure developed with elevation of the venous pressure ; yet at this time only the trivial proteinuria often found in heart failure was present and the nephrotic syndrome did not develop.

Clearly the conclusions to be drawn from one case must be cautious, but this patient's history suggests that the original nephrotic syndrome was not attributable to inadequate cardiac performance alone and casts further suspicion on the role of mersalyl. Moreover the fact that the nephrotic syndrome did not recur when the venous pressure rose with the onset of cardiac failure adds support to the evidence presented in our previous paper that venous hypertension alone does not underlie the association of nepkrotic syndrome with heart disease.-We are, etc.,

P. J. Hilton.

N. F. JONES

J. R. TIGHE.

St. Thomas's Hospital phrenics.

Where the general psychiatric hospital has remained the centre for all the psychiatric illnesses no difficulties in therapy or fulfilling meagre establishments has been found. 